1999. - №1 (22). - С. 104-110. 7. Шевчук Л. М. Форми й види групової роботи учнів / Л. М. Шевчук // Педагогіка і психологія. 2011. - №2 (71). - C. 54-62.

\title{
РИТОРИЧНІ ВПРАВИ НА УРОКАХ УКРАЇНСЬКӦ̈ МОВИ В СТАРШИХ КЛАСАХ
}

У статті розглянуто класифікації вправ з риторики, спрямовані на розвиток риторичних умінь і навичок. На їх основі автор пропонує оптимальну класифікацію вправ, щчо сприяє успішному засвоєнню риторичних знань на уроках мови.

Ключові слова: риторика, класифікація вправ, риторичні уміння і навички; підготовчі, тренувальні, підсумкові вправи.

В статье рассматриваются классификации упражнений по риторике, направленные на развитие риторических умений и навыков. На их основе автор предлагает оптимальную классификацию упражнений, которая способствует успешному усвоению риторических знаний на уроках языка.

Ключевые слова: риторика, классификачия упражнений, риторические умения и навыки; подготовительные, тренировочные, итоговые упражнения.

The article considers the existing methods of teaching the language classification exercises in rhetoric, that is directed on the development of the necessary rhetorical abilities and skills, based on them, the author offers the optimal system of exercises, which contributes to successful absorption of rhetorical knowledge of the language lessons.

Key words: rhetoric, classification of exercises, rhetorical abilities and skills; preparatory, training, final exercises.

У сучасних умовах розвитку шкільної освіти особливої актуальності набуває проблема формування в учнів риторичних умінь і навичок та застосування їх у різних сферах повсякденного життя.

Важлива роль у розв'язанні цієї проблеми належить вправам, оскільки вони дають змогу розвивати, зміцнювати і закріплювати необхідні риторичні навички, уміння, розв’язувати проблемні ситуації, збагачувати й використовувати нові знання з риторики. Академік О. Текучов зазначав, що «без вправ заняття звелися б до голої теорії», оскільки 
розібратися словесно в суті виучуваного питання навряд чи можливо без виконання практичних завдань і вправ [7, с. 80].

Логіка нашого дослідження вимагала вивчення й аналізу розроблених у методиці навчання мови класифікацій вправ, запропонованих Н. Голуб, О. Біляєвим, М. Барановим, А. Купаловою, Т. Ладиженською, В. Нищетою, В. Онищуком та ін. Учені класифікують вправи за різними ознаками: місцем проведення, тематикою, дидактичною метою, характером і способом виконання, ступенем пізнавальної активності, критерієм комунікативності, формою тощо.

Mema cmammi - проаналізувати наявні в методиці навчання української мови класифікації вправ, які спрямовані на формування риторичних умінь і навичок, а також визначити вправи, які ефективно сприятимуть засвоєнню знань 3 риторики.

Нині серед методистів немає єдиної позиції щодо класифікації вправ, кожен, керуючись різними принципами, класифікує їх по-своєму.

Відповідно до основних напрямків роботи над мовними засобами в аспекті розвитку мовлення А. Купалова визначає такі види:

1. Аналіз готового матеріалу (спостереження за питаннями та завданнями, розпізнавання та добір потрібних елементів, порівняння подібних явищ мови).

2. Перетворення поданого мовного матеріалу (мовний експеримент, синонімічні заміни мовних фактів, побудова різноманітних мовних одиниць за опорними моделями, схемами, розширення або скорочення матеріалу, редагування).

3. Створення висловлювання (вибір мовних засобів у співвідношенні з темою, конструювання елементів твору, написання твору на пропоновану чи самостійно сформульовану тему у визначеному стилі) $[4$, с. 16$]$.

Подана класифікація враховує особливості навчання риторики, оскільки забезпечує розвиток мовних і комунікативних здібностей.

М. Баранов визначає вправи, що формують: навчальномовні уміння (розпізнавальні, класифікаційні та аналітичні); правописні (орфографічні, пунктуаційні) уміння й навички; мовленнєві уміння (усний твір, усний переказ, діалог, виступ). 
Неабиякий інтерес для нашої розвідки представляють вправи, які М. Баранов поділяє на некомунікативні та комунікативні.

Метою некомунікативних вправ $\epsilon$ розвиток лексичних, синтаксичних і мовленнсвих умінь на основі імітації, утворення форм слова, зіставлення словосполучень і речень, переконструювання, добір слів на ту чи іншу смислову тему.

Комунікативні вправи пов'язані $з$ формуванням комунікативно-мовленнєвих умінь, а саме: добір матеріалу на задану тему, зіставлення робочого матеріалу, добір мовних засобів [1, с. 36-43].

У класифікації, розробленій В. Онищуком, вправи поділяються на підготовчі, тренувальні та завершальні. В основу цієї класифікації покладено дидактичну мету завдання, виконуваного учнями, ступінь їхньої активності й самостійності в роботі.

Мета підготовчих вправ полягає в тому, щоб ліквідувати прогалини в опорних знаннях, потрібних для кращого сприймання нового матеріалу. Вступні вправи проводяться після ознайомлення учнів 3 новим матеріалом для осмислення певних понять. Тренувальні вправи призначені для закріплення в учнів мовних умінь і навичок. До завершальних вправ належать проблемні завдання, виконуючи які, учні стикаються 3 нестандартними ситуаціями, що сприяє активізації їхньої навчальної роботи на уроці, творчі завдання, пов'язані з творчою уявою і розраховані на варіативність та індивідуальність виконання, i, звичайно, контрольні вправи, які проводяться для перевірки знань, умінь і навичок з риторики [5, с. 49]. Ця класифікація $є$ найбільш поширеною серед учителів-словесників, іiі систематично використовують на уроках української мови в старших класах.

Під час навчання риторики важлива роль належить комунікативним вправам, що стимулюють учнів до спілкування, мовленнєвого самовдосконалення. Однак ця класифікація не враховує повною мірою лінгводидактичні засади навчання риторики. Спробу вдосконалити цю класифікацію з урахуванням особливостей засвоєння риторики зробила Н. Голуб. У статті «Система вправ з риторики» нею обгрунтовано типологію вправ з риторики для роботи на уроках мови і в процесі самостійного вивчення, представлено зразки кожного виду вправ. Дослідниця зазначає, що сформовані вміння і навички того, хто навчається, можна застосовувати в різних 
життєвих ситуаціях, а в навчанні риторики особлива роль відводиться методу вправ.

Оскільки у вітчизняних закладах середньої освіти вивчаються тільки елементи практичного курсу риторики, Н. Голуб класифікує вправи з риторики таким чином:

- підготовчі вправи, які спрямовані на формування вмінь психологічно налаштовувати себе на успішний виступ, визначати тему виступу, формулювати мету, тезу, моделювати аудиторію, добирати й опрацьовувати матеріал;

- тренувальні вправи, що сприяють тренуванню дихання, голосу, дикції, інтонації, пам’яті; відпрацюванню жестів і міміки; формуванню навичок виголошувати промови частинами і повністю;

- творчі вправи, які спрямовані на формування умінь i навичок композиційно, логічно і стилістично правильно будувати текст виступу, використовувати елементи зацікавлення аудиторії; оригінально оформлювати логічну схему тощо;

- аналітичні, що розвивають аналітичне мислення, формують уміння й навички риторичного аналізу тексту чи його частин, аналізу конкретної ситуації, публічного виступу [3, c. 3].

Цінною для нашого дослідження є типологія вправ, класифікована Т. Ладиженською, яка значною мірою враховує своєрідність опанування риторичних відомостей й формування риторичних умінь і навичок. Дослідниця визначає:

- дихальні вправи (передбачають тренування таких якостей голосу: гучності, сили, темпу, тембру, витривалості тощо);

- дикційні вправи (грунтується на скоромовках, які виконують допоміжну функцію - відпрацювання інтонаційних вправ);

- інтонаційні (передбачають роботу з інтонемами, так званими, інтонаційними знаками, які допомагають розрізняти інтонаційно-смислові відрізки в мовленні);

- стилістичні вправи (передбачають аналіз тексту з точки зору його стильової приналежності; аналізувати стиль в риториках різних авторів з урахуванням мовної особистості автора; виявляти мовні та мовленнєві явища, у яких більш яскраво виражається індивідуальний стиль мовлення; характеризувати й оцінювати індивідуальний стиль мовлення);

- інформуючі (передбачають повідомлення якихнебудь відомостей, узагальнення інформації, отриманої із 
книг, журналів, статей, спостережень, досвіду, а також знайомство $з$ такими жанрами усного інформативного мовлення, як реферативне повідомлення або доповідь);

- аргументативні (такі вправи поглиблюють раніше отримані знання про предмет мовлення; учать виявляти елементи аргументації в жанрах повсякденного спілкування) [6, c. 10].

Спираючись на класифікації Т. Ладиженської, Н. Голуб та ін., нами визначені такі види вправ для старших класів:

1) Підготовчі вправи (вибір теми, опрацювання матеріалу, створення власного архіву, підготовка виступу, моделювання ситуації).

- Прочитайте текст. Визначте, хто може бути його адресатом.

На жаль, у нас дехто вважає, що культурне мовлення потрібне лише представникам таких професій, як учителі, журналісти, дипломати. Ця хибна думка породжує скептичне ставлення майбутніх «технарів» до мови. I тоді в їхньому мовленні звичними стають стилістичні помилки на зразок: «у місяці березні», «витрачання коштів за цільовим призначенням», «кількісне збільшення», «для здійснення перевірки», «мозолі на долонях рук», «відступати назад», «моя власна думка», «моє особисте враження», «температура повітря плюс 5 градусів тепла». А в побутовому вжитку часто чуємо «кровать», «форточка», «ковьор», «полотенце», «тряпка», «убрано», «часи», «прийомник» і тощо. Така мовна неохайність негативно позначається на чистоті мовлення, яка є свідченням і культури мислення, і культури поведінки (За Н. Бабич).

- Прочитайте текст. Знайдіть у позииії автора слабкі місия і доведіть, щуо лукавство, нещчирість - це таки людська вада.

Лукавому докоряють у тому, що він міняє своє ставлення до того самого залежно від зміни обставин. Це часто справді виглядає непривабливо. Однак, завдяки такій поведінці, лукава людина привчається розглядати всякий предмет багатосторонньо, виявляти різні його грані і властивості. Це, в свою чергу, хороший грунт для формування недогматичного, гнучкого розуму.

I взагалі, я не розумію, за що засуджувати лукаву людину? Сучасне життя настільки складне й різноманітне, воно влаштоване так суперечливо, що вимагає від людини мати не два 
навіть, а двадцять два обличчя. I хто їх рахував? Кожен 3 нас грає безліч ролей, і як би ми впоралися 3 цією нелегкою справою, якби не виховання лукавством? Не я - сучасне суспільство саме щокроку виправдовує лукавство і вимагає його, неначе голодний - шматка хліба (Т. Флешлі).

- Підготуйте план виступу на одну з тем:

Кого можна назвати мовною особистістю.

Освічена людина - корисна людина.

Навіщо треба вивчати риторику?

Спортивні новини.

Запропоновані вправи сприяють розвитку не лише риторичних умінь і навичок, а й комунікативно-мовленнєвих.

2) Тренувальні вправи (дихальні, дикційні, інтонаційні).

Дихальні.

- Прочитайте рядки з поезї Л. Костенко, зробивии вдих повітря після останнього слова.

А місяць все такий же,

Він - місяць, місяченько,

Як вчора, позавчора

I хтозна ще коли!

I добре, що над нами

Висить він височенько,

А то б уже й на ньому

Болото розвели.

Л. Костенко.

Дикційні вправи.

- Прочитайте скоромовки.

Скорохвацький скоробреха, словесний сальтоморталець, старо-самбірець Спиридон Скоробагацько склав скороспіхом скоромовку: «Славнозвісна сливоока сова Сандра сполуденок співа серенади».

Щойно щуку щипавка щипнула. Щука-щупачка щововкнула:

- Щось щемить! Щонайбридкіша Щипавко-щепійко, щезни!..

Хан Ходжа - ханжа. Ханиця Ходжиця - ханжиця.

Кинув кріп Прокіп в окріп,

У окропі, окрім кропу, кипить короп для Прокопа.

Осениця оранжево-червоним олівцем обзолотила околиці Опішні. Одухотвореної осені ораторія!

Інтонаційні вправи. 
- Спробуйте вимовити фрази «Може, ще раз сонце правди хоч крізь сон побачу...» (Т. Шевченко), «Видно, ми не поїдемо на екскурсію» рішучим, байдужим, несміливим, життєрадісним, серйозним, грубим, ввічливим, доброзичливим, наказовим, схвильованим, улесливим, зверхнім, веселим, роздратованим, легковажним, пригніченим голосом.

- Пригадайте свою останню подорож: якою вона була - радісною чи сумною? Спробуйте розповісти про цю подію, передаючи інтонацією мовлення своїх друзів та близьких.

Подані вправи доречно виконувати перед усним переказом, твором, виступом.

3) Підсумкові вправи (аналіз виступу, висновок).

- Сформулюйте запитання для однокласників за змістом виступу. Розкажіть, щуо нового ви дізналися з тексту.

- Складіть усний відгук про виступ однокласника.

Підсумкові вправи формують уміння визначати тему й основну думку висловлювання, стилі, типи мовлення, розвивають уміння критично мислити.

Отже, запропонована класифікація вправ передбачає успішне опанування учнями риторичними вміннями і навичками, забезпечення розвитку комунікативних здібностей, уміння думати, розуміти, переконувати.

\section{Література}

1. Баранов М. Т. Выбор упражнений для формирования умений и навыков / М. Т. Баранов // Русский язык в школе. - 1993. - № 3. С. 36 - 43. 2. Бєляєв О. М. Вправи в навчанні мови / О. М. Біляєв // Українська мова і література в школі. - 2004. - № 6. - С. 4. 3. Голуб Н. Б. Система вправ з риторики / Н. Б. Голуб // Українська мова і література. - 2011. - № 6. - С. 2-8. 4. Купалова А. Ю. Типология упражнений // Методика развития речи на уроках русского языка / А. Ю. Купалова, Н. Е. Богуславская, В. И. Капинос и др. / под. ред. Т. А. Ладыженской. - [2-е изд.]. - М. : Просвещение, 1991. - С. 15 - 17. 5. Онищук В. О. Дидактичні основи засвоєння учнями мовних навичок і умінь / В. О. Онищук // Українська мова i література в школі. - 1971. - № 3. - С. 48 - 53. 6. Риторика. 11 класс: [метод. рекомендации] / под ред. Т. А. Ладыженской. М. : Ювента; Баласс, 2004. - 128 с. 7. Текучев А. В. Методика русского языка в средней школе / А. В. Текучев. - М. : Просвещение, 1980. $-414 \mathrm{c}$. 